\section{Publications of Interest}

Biodiversity: Implications for Forest Management in New Brunswick. 1992. Mark R. Roberts. University of New Brunswick, Faculty of Forestry, UNB Forestry Focus, Volume 17, Number 4, Fall 1992. 3 p.

Improving Planning for Ontario's Natural Resources. Discussion Paper. 1992. Ontario Ministry of Natural Resources. 20 p.

Balsam Fir Christmas Tree Needle Retention Versus Timing of Bud Flush. 1992. Canada-Nova Scotia Cooperation Agreement for Forestry Development. Nova Scotia Dept. Natural Resources, For. Res. Rep. 41. 8 p.

Quick Cruise Summary Program User Manual. 1992. Canada-Nova Scotia Cooperation Agreement for Forestry Development. Nova Scotia Dept. Natural Resources, For. Res. Rep. 42.12 p.

Hardwood Forest Development Project. Projet de mise en valeur de forêts d'arbres feuillus. 1992. Forestry Profiles/Foresterie - sur le vif. Canadian International Development Agency/Agence canadienne de développement international.

Canada's Green Plan and the Earth Summit. 1992. Government of Canada. DSS cat. no. En21-120/ 1992E. 25 p. (Issued also in French under the title: Le Plan vert du Canada et le Sommet Planète Terre.)

Earth Summit: A Positive Start for Global Action. Canada and the Earth Summit. Volume 1, no. 5, Autumn 1992. Bilingual newsletter produced by Environment Canada, Ottawa, Ontario $\mathrm{K} 1 \mathrm{~A} 0 \mathrm{H} 3$.

Proceedings ENVIROFOR ' $92-\mathrm{A}$ Provincial Dialogue on Nova Scotia's Forests, Oak Island Inn, Nova Scotia, May 3-5, 1992. Hosted by Canadian Forestry Association, Canadian Institute of Forestry - Nova Scotia Section - and Acadia Centre for Wildlife and Conservation Biology. Edited by Tom Herman and Søren Bondrup-Nielsen. Published by The Centre for Wildlife and Conservation Biology, Acadia University. $55 \mathrm{p}$. The publication includes opening remarks, objectives, plenary speeches by Joe O'Neill, Herb Hammond and George Child, group reports on ecological diversity and economic stability, forest management, wildlife and water, air, soil and forest relationships, landownership, special places, and recreation and aesthetic values, common themes and issues, resolutions, and closing remarks. Names of facilitators and participants are also included.

\section{FOREST ENGINEERING RESEARCH INSTITUTE OF CANADA}

Harvesting Low-volume Pine Stands in the Williams Lake Timber Supply Area, British Columbia. 1992. Bjorn Andersson. Tech. Rep. TR-106. 24 p.

Wood Moisture Variation in Woodlands Inventory: A Case Study. 1992. J.-F. Gingras and J. Sotomayor. Tech. Note TN-192. 6 p.

Future Woodlands Equipment Needs in Eastern Canada: 1992-2001. 1992. J.-F. Gingras and M. Ryans. Tech. Note TN-193. 8 p.

\section{US FOREST SERVICE}

The Aggregate Timberland Assessment System - ATLAS: A Comprehensive Timber Projection Model. 1992. John R. Mills and Jonna C. Kincaid. Pacific Northwest Research Station, Gen. Tech. Rep. PNWGTR-281. $160 \mathrm{p}$.

Economic Implications for Management of Structural Retention on Harvest Units at the Blue River Ranger District, Williamette National Forest, Oregon. 1992. James F. Weigand and A. Lynn Burditt. Pacific Northwest Research Station, Res. Note PNWRN-510. 17 p.

Geographic Variation in Speed of Seed Germination in Central Oregon Ponderosa Pine. 1992. John C. Weber and Frank C. Sorensen. Pacific Northwest Research Station, Res. Pap. PNWRP-444. 12 p.

The Alaska Vegetation Classification. 1992. L.A. Viereck, A.R. Dryness,
A.R. Batten and K.J. Wenzlick. Pacific Northwest Research Station, Gen. Tech. Rep. PNW-GTR-286. 278 p.

Production and Assessment of Red Alder Planting Stock. 1992. M. A. Radwan, Y. Tanaka, A. Dobkowski and W. Fangen. Pacific Northwest Research Station, Res. Pap. PNWRP-450. 13 p.

Early Survival and Height Growth of Douglas-fir and Lodgepole Pine Seedlings and Variations in Site Factors Following Treatment of Logging Residues. 1992. W. Lopushinsky, D. Zabowski and T.D. Anderson. Pacific Northwest Research Station, Res. Pap. PNW-RP-451. 22 p.

Age of Hybrid Poplar Stools at First Cut Influences Third-year Cutting Production. 1992. David Tolsted and Edward Hansen. North Central Forest Experiment Station, Res. Pap. NC-537. $3 \mathrm{p}$.

Regional Impacts of Technical Change: The Case of Structural Particleboard in the United States. 1992. Zhi Xu, David N. Bengston, Hans M. Gregersen and Allen L. Lundgren. North Central Forest Experiment Station, Res. Pap. NC-304. 13 p.

Calculating Competition in Thinned Northern Hardwoods. 1992. Sharon A. Winsauer and James A. Mattson. North Central Forest Experiment Station, Res. Pap. NC-306. 10 p.

Ground-application Trial of Hexazinone on the Ottawa National Forest. 1992. Michael A. Wehr, James A. Mattson, Roger W. Bofinger and Robert L. Sajdak. North Central Forest Experiment Station, Res. Pap. NC-308. $34 \mathrm{p}$.

Wildlife of the Upper Great Lakes Region: A Community Profile. 1992. Janine M. Benyus, Richard R. Buech and Mark D. Nelson. North Central Forest Experiment Station, Res. Pap. NC-301. 27 p.

Estimation of Shrub Leaf Biomass Available to White-tailed Deer. 1992. Lynn L. Rogers and Ronald E. McRoberts. North Central Forest Experiment Station, Res. Pap. NC-307. $16 \mathrm{p}$. 
Viability of Red Pine Seed Stored Up to 54 Years. 1992. Glen W. Erickson and Robert G. Barse. North Central Forest Experiment Station, Res. Pap. NC-360. 2 p.

\section{FORESTRY CANADA}

Development and Structure of the Canadian Forest Fire Behavior Prediction System. 1992. Fire Danger Group and Science and Sustainable Development Directorate. 64 p.

The Silviculture Conference. Stewardship in the New Forest. 1992. Forestry Canada, Ottawa, Ontario.

Economics of Private Woodlot Management: A Literature Review. 1992. G. D. Savage and K.L. Runyon. Maritimes Region, Information Rep. M-X-182 E/F.

\section{Journal Bargains for Institute Members}

The Canadian Journal of Forest Research is available to CIF/IFC members at a special price of $\$ 36.00$ per year, plus $\$ 2.52$ for Goods and Services Tax. The normal rate for individual subscribers to the journal direct from National Research Council is $\$ 82.00$. All NRC journals are available to members at greatly reduced prices. Send orders with payment to the national office.

\section{Book Reviews/Revue de livres}

Wildlife of Atlantic Canada \& New England

Text by Gary Saunders

Photography by Wayne Barrett

Most of us think of Atlantic Canada and New England as a "people" place with pircturesque seacoasts, farms and cities. But together, geology topography, climate and time have created unique and diverse wildlife - land and sea mammals, birds, amphibians and reptiles - in a region that has extensive wilderness areas. In Wildlife of Atlantic Canada \& New England, Gary Saunders and Wayne Barrett examine our fascination with the regions' wildlife through informative text and evocative photographs. For, the more that urbanization squeezes nature from our everyday experience, the more we seem to look to nature for solace and guidance.

Wildlife of Atlantic Canada \& New England is a celebration of the diversity of wildlife that continues to thrive in our midst despite the long history of settlement of the Northeast. From tiny shrews hunting day and night to moose dining in shallow lakes; from the playful otter to the humpback whale, the "songster of the sea"; from the "whoosh" of wings of the semi- palmated sandpipers to the great horned owl gliding soundlessly on softfeathered wings; from salamanders to eastern painted turtles, Gary Saunders and Wayne Barrett describe and illustrate with photos more than 80 species.

Many may recognize Gary Saunders as former editor-in-chief of NS Conservation. An avid naturalist, Gary resides in Old Barns, N.S. His work in public forestry education has won the Seaborne and John C. Currie awards. $\mathrm{He}$ is the author of several books including September Christmas, Alder Music, and Rattles and Steadies, as well as more than 60 published articles and essays. $\mathrm{He}$ is also an accomplished artist.

Wayne Barrett is one of Canada's finest photographers. He has published more than 10 books, and his impages have appeared in magazines such as Equinox, Canadian Geographic, and Nature Canada. He lives in St. Catharines, P.E.I.

Gary Saunder's delightful style and his love for nature shine in this colorful narration on the wildlife of the region, while Wayne Barrett has managed to capture his subjects most vividly. The book provides enjoyable, informative reading for all. Wildlife of Atlantic Canada \& New England is published by
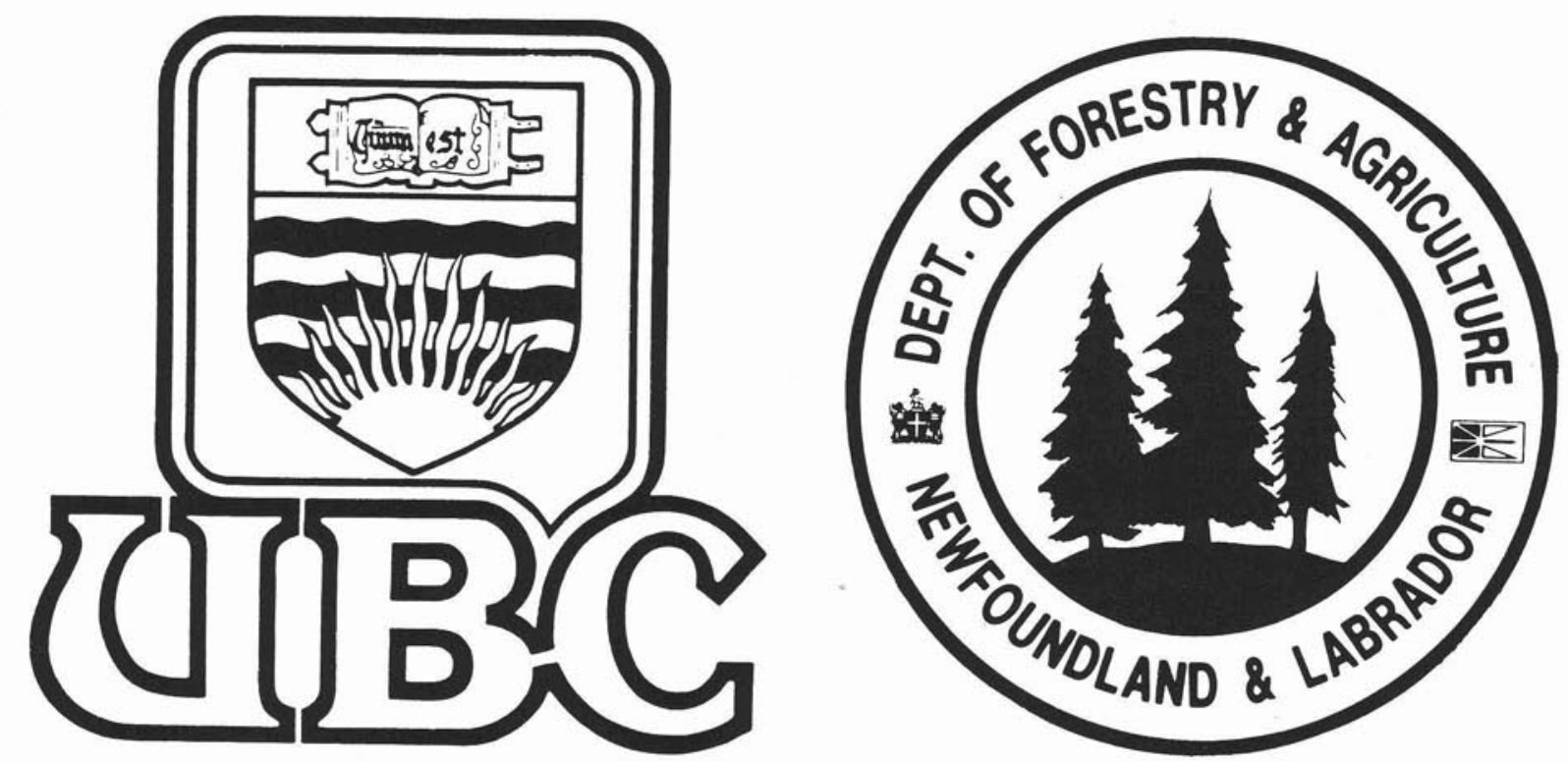

CIF/IFC Corporate Sustaining Members 